\title{
THE LEGAL WORLD OF UNMARRIED COUPLES: REFLECTIONS ON "DE FACTO RELATIONSHIPS" IN RECENT NEW ZEALAND LEGISLATION
}

\author{
Bill Atkin*
}

This article is a revised version of a paper presented at a conference in Vienna 16-20 September 2008, the $13^{\text {th }}$ World Conference of the International Society of Family Law. The paper notes how the New Zealand legislation for most purposes equates the legal position of de facto, civil union and married couples. The main part of the paper focuses on the key definition of "de facto relationship" and draws attention in particular to the leading High Court decision of Scragg v Scott. While there will inevitably be borderline situations, most are likely to fall easily within or outside the definition.

It is very fitting to have in this issue of the Law Review a piece by Professor Atkin on New Zealand's relationship property law: in the 1970s when the original matrimonial property statute was enacted, Professor Angelo and Professor Atkin together made submissions to Parliament and subsequently co-authored articles on the subject.

\section{INTRODUCTION}

The Western phenomenon of increasing cohabitation outside marriage hardly needs documenting. ${ }^{1}$ From a legal point of view, it cannot be ignored. There are several approaches that can be taken, for example: laissez faire, leaving the parties to rely on the general law for any remedy; an "opt-in" scheme, which enables parties to jointly sign up to a legislatively determined regime (or perhaps to choose from more than one option); a special statutory scheme that is imposed on the parties, possibly with an opt-out mechanism; or the equation of unmarried relationships with

* $\quad$ Professor of Law, Victoria University of Wellington, New Zealand.

1 In New Zealand with a total population of a little over 4 million, according to the 2006 census, 428,130 people lived together unmarried, compared with 87,960 in 1981 when figures were first collected. Two in five aged between 15 and 44 were in de facto relationships. Also according to the 2006 census there were 6171 couples living in same-sex relationships, 2655 male couples and 3516 female couples. 
marriage (and civil unions or registered partnerships if they exist in the country). In 2001 New Zealand elected to take the last option.

There are good reasons for distinguishing marriage (plus civil unions, civil partnerships or similar institutions) from non-marriage: freedom of choice and association; "one size does not fit all"; the wide variety of relationships makes it inappropriate to equate them to marriage; priority should be given to marriage either for ideological and cultural reasons or because of a sense that the public commitment in marriage makes it a better bet for secure family life.

However, there are also good reasons why the law should treat unmarried partners much the same as married couples: their relationships are usually functionally very similar to marriages with similar needs and problems requiring resolution; there are advantages in drawing upon the same body of jurisprudence instead of re-inventing the wheel each time an issue arises; recognising unmarried relationships in financial statutes is unlikely to undermine marriage because the legal issues that arise in each case are usually when the marriage or relationship is in strife or when one of the parties has died; many countries have laws that militate against discrimination on the basis of marital or other status; and definitions of the relevant relationships and a duration requirement as a condition of jurisdiction (in New Zealand three years) can weed out the fringe associations that should be outside a marriage-based regime.

The main object of this article is briefly to explore the New Zealand definition of "de facto relationship" and its accompanying jurisprudence in the hope that a little light may be shed on the issues that many jurisdictions, especially in Western countries, are facing. In New Zealand, there has been a steady flow of litigation over definitions and, while each case turns intensely on its own particular facts, guidance is slowly emerging from the courts.

While it is suggested that the New Zealand approach - in force now for over seven years - is working satisfactorily enough for the majority of couples, the uncertainty surrounding the question of definition may nevertheless be of concern to some people. Others may still be troubled as a matter of principle by the unification of marriage, civil unions and de facto relationships. That is a matter of course for the policy-makers of each jurisdiction to wrestle with. ${ }^{2}$

\section{BROAD COMMENTS ON THE NEW ZEALAND APPROACH}

New Zealand decided to go for arguably the simplest option when reforming its laws on de facto relationships. Instead of developing an alternative set of rules, as for example has been proposed by the English Law Commission, ${ }^{3}$ Parliament decided in essence to equate de facto relationships with

2 For a very comprehensive recently published work on the question, see Göran Lind Common Law Marriage A Legal Institution for Cohabitation (Oxford University Press, New York, 2008), especially chapter 14 "Arguments for and against Common Law Marriage".

3 Cohabitation: The Financial Consequences of Relationship Breakdown Law Com No 307 (London, 2007). See also Gillian Douglas, Julia Pearce and Hilary Woodward "The Law Commission's Cohabitation 
marriages, the main policy choice to this effect being made after a change of government in 1999. ${ }^{4}$ The decision to incorporate de facto relationships into the matrimonial law divided Parliament: a narrow majority voted in favour but a subsequent vote to include same-sex couples was passed with a much greater majority.

So, in New Zealand, the same rules generally apply to marriages, civil unions (more recently created by the Civil Union Act 2004) and de facto relationships for the purposes of property division, maintenance and inheritance. ${ }^{5}$ There is a similar equation for most of the rest of the law, with some notable exceptions such as adoption, presumptions of parenthood, ${ }^{6}$ the effect of a marriage or civil union on pre-existing wills, and the effect on wills of the dissolution of a marriage or civil union. ${ }^{7}$ The major reforms affecting property were passed in 2001, coming into force on 1 February 2002. However, rules on contracting out of the statutory regime came into force on 1 August 2001, thus enabling de facto couples to take advantage of this procedure in advance of the substantive changes becoming effective. In practice the most significant of the reforms is the extension of the Property (Relationships) Act to de facto relationships. All the subsequent case law of any note relating to the 2001 reforms has come under this Act, rather than the others that were amended.

In contrast to other British Commonwealth countries such as Australia and England, in New Zealand "relationship" property is divided, usually on the parties' separation, according to a prima facie rule of equal sharing. There is one main exception to equal sharing: where such sharing would be "repugnant to justice" because of "extraordinary circumstances". ${ }^{8}$ However, other important changes were made to the law in 2001 and in particular the court was empowered to grant "compensation" for economic disparity. ${ }^{9}$ This is not the place to explore this new power, ${ }^{10}$ suffice

Proposals: Applying Them in Practice" (2008) 38 Fam Law 351, and Tom Guthrie and Hilary Hiram "Property and Cohabitation: Understanding the Family Law (Scotland) Act 2006" (2007) 11 Edinburgh LR 208. The British Government is deferring implementation of the Law Commission's proposals until it sees research on the Scottish law: "Cohabitation Delay" [2008] Family Law 374.

4 For a discussion of the reform process, see Bill Atkin and Wendy Parker Relationship Property in New Zealand (Butterworths, Wellington, 2001), especially chapter 1.

5 See amendments to the Property (Relationships) Act 1976 (originally called the Matrimonial Property Act 1976), the Family Proceedings Act 1980, the Family Protection Act 1955, and the Administration Act 1969.

6 Status of Children Act 1969, s 5 and Part 2.

7 Wills Act 2007, ss 18 and 19.

8 Section 13, Property (Relationships) Act 1976. In a small number of situations, there is also an exception where cohabitation has been short (in general, three years or less): Property (Relationships) Act 1976, ss 14, 14AA and 14A. See below, Part V.

9 Sections 15 and 15A, Property (Relationships) Act 1976. 
it to say that in extending the 1976 Act to de facto couples Parliament was not simply applying equal division to them: it was going much further and permitting the court in effect to award unequal division, most likely in favour of the party with the least property. This is a far cry from the law that previously applied and makes it all the more significant whether two people fall within the definition of "de facto relationship" or not.

So, at first sight the New Zealand approach of bringing de facto couples under the same umbrella as married couples looks like a simple route. Especially is this so when the regime for married couples has a relatively straightforward rule for division of the relevant property. There are none of the potential difficulties of, for example, the English Law Commission's proposal that relies on identifying qualifying contributions and ongoing economic disadvantage. However, the apparent simplicity is belied when we take account of the new discretionary provisions on economic disparity: this is a complexity that was not present in the original 1976 Act.

\section{QUALIFYING RELATIONSHIPS}

One of the main questions that relates exclusively to de facto relationships, as opposed to marriages and other institutions like civil unions, is their definition, something that will arise whatever shape a legislative system for such relationships possesses. Marriages and civil unions are evidenced by their public registration. There is no equivalent for de facto relationships. The nearest is the parties' own de facto cohabitation contract, if they have one. Getting the formula for de facto relationships right is crucial: if it is wrong, either too many couples fall within the scheme or too many are excluded. The reason for this is the variety of personal associations that human beings enter. Yet, such variety also means that finding a bright-line formula is an impossible task. As we shall see with the New Zealand example, an element of imprecision is inevitable and much depends on the judicial skill in applying the legislative language to particular situations.

The jurisdiction of the court depends on whether the parties have a qualifying relationship. There are three aspects to this:

1. The main issue is whether a couple falls within the statutory definition of "de facto relationship" (set out below). This is the first but not the only essential hurdle.

2. The length of the relationship is also critical. As a general rule, to qualify, a de facto relationship must have lasted three years. There are exceptions, discussed later in Part $\mathrm{V}$, that may apply. The three-year rule means that it may be vital in individual cases to know precisely when a de facto relationship began and ended. Two people may for example have had an association that

10 See recently Bill Atkin "Economic disparity - how did we end up with it? Has it been worth it?" (2007) 5 NZ Family Law Journal 299. See also the excellent writing of Joanna Miles "Financial Provision and Property Division on Relationship Breakdown: A Theoretical Analysis of the New Zealand Legislation" (2004) 21 NZULR 268 and "Dealing with Economic Disparity: An Analysis of Section 15 Property (Relationships) Act 1976" [2003] NZ Law Rev 535. 
lasted a lot longer than three years but was legally a de facto relationship for only part of that period. Was there a legal turning point that converted the relationship into a "de facto relationship"? Or that brought about its end?

3. Were the parties in a statutorily defined de facto relationship on or after 1 February 2002 when the law came into effect? The statutory regime does not apply to de facto relationships that ended before that date.

If the parties do not satisfy these three jurisdictional conditions, then they must rely on the old rules of common law and equity. As a generalisation, the New Zealand courts developed an approach to constructive trusts (the device frequently resorted to) that is more generous than, for example, England's. ${ }^{11}$ Despite this, there remains a considerable element of unpredictability about the grant of any equitable award and its quantum, and an applicant is likely to be much better off under the statutory scheme. The three jurisdictional questions outlined above are therefore ones that can have a dramatic effect on the financial position of the persons involved.

The phrase "de facto relationship" and its companion "de facto partner" are used in preference to other versions such as the cumbersome language, employed in the past in some New Zealand legislation, that talks about people who, although not married, live together in a relationship in the nature of marriage. The language of "cohabitation" and "cohabitant" found in a lot of the literature is also avoided: that language ought surely to apply to married and civil union persons who also "cohabit". During the passage of the legislation, the definition of "de facto relationship" was revised by the parliamentary select committee, which inter alia borrowed the phrase "living together as a couple" from the New South Wales Property (Relationships) Act 1984. We now turn to consider the definition in more detail.

\section{DEFINING DE FACTO RELATIONSHIPS}

\section{A The "Mistress" Story}

An article in a Sunday newspaper was headed "Dumped Mistress Sues for Share of Assets". ${ }^{12}$ The subtitle was "Warning: if you're having an affair, your lover could take half". The headline implied that the "mistress" was successful - and worryingly so - in obtaining a large share of the man's property. In fact, the woman in $C v S$ failed. ${ }^{13}$ Despite the tendentious "mistress" language and the printing of the story over 18 months after the judgment, the article could well give quite the

11 See especially the leading Court of Appeal decision in Lankow v Rose [1995] 1 NZLR 277.

12 Sunday Star Times 27 April 2008, A3.

13 C v S (28 September 2003) FC Dun FAM-2005-012-157 (Family Court). There was a separate judgment dealing with the journalist's application to be allowed to publish her story about this case: JAC v GCS [Leave for publication] [2008] NZFLR 715 (Family Court) per Judge Smith. 
wrong impression about the operation of the law. Even so, when we examine the facts a little more closely, we might wonder whether the woman was not actually hard done by.

The association between the two parties had lasted 20 years. The man was married to another woman, who appeared either to turn a blind eye to the "affair" or was unperturbed by it. The man and his wife had a settled life with two children, both teenagers by the time of the proceedings. One of the telling matters in the judgment was a comparison between the two associations: the man and the claimant did not share a common residence. This is not in itself fatal, as we shall see, but in the circumstances of this case, was a strong factor against their having been in a de facto relationship. The man's "all-pervading intent was to ensure security for his children and family life", something over which he was not prepared to compromise. ${ }^{14}$ The Judge saw the man and the "mistress" as a couple but not two people "living together as a couple" - a key phrase in the legislation.

The outcome of the case is arguably correct and may re-assure those who fear that legislation for unmarried couples may reach too far. The two never set up home together, but had separate properties that each visited. The relationship was intense and sexual but rarely did they spend full nights together. The judge found that there was "no financial dependence, interdependence or support as between the parties" and the occasional gifts and payments "at best can be considered 'expenses' associated with continuing to want to either impress, maintain or civilly contribute to an ongoing enjoyable relationship". ${ }^{15}$ They did not have children together and had no proper family life. Although they sometimes appeared in public together, the association was clandestine and discreet for the first eight years during which the woman's own marriage remained intact and, even after that marriage ended, the parties still maintained "a degree of circumspection". ${ }^{16}$ Basically, what they did was nothing more than many "dating" couples may do. There was little really "marriage-like" in the association, in sharp contrast to the life that the man had with his wife and children.

On the other hand, the judgment left the woman high and dry. Unless she could establish a claim in common law or equity - perhaps unlikely on the facts, or likely to be very small in quantum - the woman who had devoted 20 years of her life to the man came out with nothing that was not already hers. Is it enough to say that she had her reward at the time and, now that the association is ended, she cannot expect anything more? Does the case illustrate that the New Zealand "all or nothing" approach that follows from the unification of de facto and matrimonial laws is too blunt? A more nuanced scheme could perhaps allow for the variety of personal associations that people enter. I do not recommend this, for alternative schemes may in the end be too complex: most couples fall easily

14 Ibid, para 89.

15 Ibid, paras 95 and 105.

16 Ibid, 137. 
within or outside the standard definition, and the exceptional case should not govern the key legal policy decisions.

\section{B The Statutory Definition - Living Together as a Couple}

What exactly is the definition of a de facto relationship? ${ }^{17}$ The first part of section $2 \mathrm{D}$ of the Property (Relationships) Act 1976 reads as follows:

(1) For the purposes of this Act, a de facto relationship is a relationship between 2 persons (whether a man and a woman, or a man and a man, or a woman and a woman)-
(a) who are both aged 18 years or older; and
(b) who live together as a couple; and
(c) who are not married to, or in a civil union with, one another.

Several preliminary points can be made about this:

1. It covers both heterosexual and homosexual relationships. For the most part, New Zealand law no longer discriminates on the basis of sexual orientation, although two notable exceptions are marriage and adoption, which are not available to same-sex couples.

2. A de facto relationship can be between two people only. The classic ménage à trois falls outside the definition. However, there is no reason why there cannot be more than one contemporaneous de facto relationship, as this is expressly contemplated by section $52 \mathrm{~B} .{ }^{18}$ The ménage à trois could actually be a triangular set of three relationships.

3. The age requirement is a little curious. It coincides with the age when two people can enter a de facto relationship without parental consent. ${ }^{19}$ However, if two people do have parental consent for a de facto relationship - or alternatively the consent of the Family Court - then why should they not be treated like any other relationship for property purposes? From a practical point of view, few teengers are unlikely to have any property of note that could become subject to the Act, but the principle is nevertheless obscure.

4. The key phrase in subsection (1) is "live together as a couple". This is the concept upon which $C v S$ (above) turned. The parties must be more than a couple: a boyfriend and girlfriend are a

17 For a helpful article, see Simon Jefferson "De facto or 'Friends with Benefits'?" (2007) 12 NZ Family Law Journal 304.

18 Section 52A, Property (Relationships) Act 1976, also provides for competing claims where there is a marriage (or civil union) and a de facto relationship. Section 52B deals with the situation where there are two de facto relationships.

19 See s 46A, Care of Children Act 2004, which was however not enacted until 2005, well after s 2D of the Property (Relationships) Act 1976 was passed. 
couple, but may simply be "going out", not living together. Furthermore, residing at the same address does not mean that there is a de facto relationship. As one judge out it, "[t]he phrase 'as a couple' provides a distinction from parties living together as friends or flatmates. It does not dilute the primacy of living together". ${ }^{20}$ This concept is discussed more fully shortly

\section{Living Together-All the Circumstances}

Subsection (2) is important because it elaborates on the concept of living together as a couple:

(2) In determining whether 2 persons live together as a couple, all the circumstances of the relationship are to be taken into account, including any of the following matters that are relevant in a particular case:
(a) the duration of the relationship:
(b) the nature and extent of common residence:
(c) whether or not a sexual relationship exists:
(d) the degree of financial dependence or interdependence, and any arrangements for financial support, between the parties:
(e) the ownership, use, and acquisition of property:
(f) the degree of mutual commitment to a shared life:
(g) the care and support of children:
(h) the performance of household duties:
(i) the reputation and public aspects of the relationship.

Several things should be noted about this list:

First, it is not an exclusive list. Other factors may be taken into account.

Secondly, the list is not one to be assessed by counting up ticks and crosses - some factors may be more relevant to one situation than others.

Thirdly, the list must not overshadow the central concept itself of living together. Asher $\mathrm{J}$ emphasised this point in $L v P$ [Division of property] where on appeal he thought that the Family Court judge had "treated a number of individual factors listed in s $2 \mathrm{D}(2)$ as determinative of the existence of a de facto relationship rather than treating them as no more than factors to assist the Court in deciding on the primary issue, namely whether the two parties were living together as a couple". ${ }^{21}$ In that case, it was accepted that the parties had lived in a de facto relationship, which

20 L v P [Division of property] [2008] NZFLR 401, para 34 (HC).

21 Ibid, para 48. 
ended on 8 November 2003. Because of the three-year rule, the critical question was when the de facto relationship began. The parties developed their association throughout 2000 and in October decided to live together. They found an apartment the next month and moved in, it was held, on 8 December 2000. If there was a de facto relationship in October, the relationship fell outside the three-year rule and within the Family Court's jurisdiction. On the other hand, if 8 December was the key date, then it fell within the three-year rule and outside the Court's jurisdiction unless one of the exceptions to the three-year rule applied. ${ }^{22}$ In choosing the earlier date, the Family Court judge had been influenced, wrongly according to the appellate judge, by the parties' decision to live together rather than the date when they physically assumed a common residence and commenced a shared life. Essentially, nothing changed in their life in October. All the changes occurred in December. ${ }^{23}$

$L \vee P$ [Division of property] was followed in a case where the parties had had an association from 1991 until late 2006. ${ }^{24}$ They had had a child together and shared accommodation from 1998 (although the man argued that they had done so much earlier). At first glance this looked like a de facto relationship, but it was held that, while "the parties lived in an arrangement" they did not live together as a couple. Judge Walsh said: "As time went by, this arrangement consolidated more by default and not by agreement between the parties". ${ }^{25}$ The truth was that the woman had been a prostitute and was a lesbian. According to the judge, "[h]er various relationships and liaisons are consistent with her view she did not want to commit herself to a relationship with another party and live with that party as a couple". ${ }^{26}$ The question of other liaisons is picked up later in this article but one slightly disturbing feature of the judge's dicta is the implication that the test is essentially subjective rather than objective. In a different statutory context, the Social Security Act 1964, Panckhurst $\mathrm{J}$ has emphasised that the test is objective and that words such as "voluntary" and "consensual" add little. ${ }^{27}$ Thus there is no need to find an agreement between the parties nor, surely, should the views of one of them be decisive. ${ }^{28}$ An "arrangement" may therefore be transformed "by default" into a de facto relationship. If all Judge Walsh was doing was checking the level of mutual

22 This is discussed later in Part V, where it is noted that the woman was successful in invoking the "substantial contribution" exception and was awarded $30 \%$ of the relationship property.

23 The Family Court judge had also been influenced by the wrong assumption that the parties had embarked on a fertility programme by October 2000 when this did not in fact occur until June 2001.

24 SPM v PJS (9 May 2008) FC Mas FAM-2007-035-00200, (Family Court) per Judge Walsh.

25 Ibid, para 95.

26 Ibid, para 77.

$27 H v$ Chief Executive of the Ministry of Social Development [2008] NZFLR 982 (HC). Interestingly, this case involved a relationship that the appellant regarded as "platonic" because the parties occupied separate bedrooms. They were still held to have been in a relationship in the nature of marriage.

28 In Part IV(f) we note that the position may be different in relation to the ending of a relationship. One party's unilateral change of heart may be telling. 
commitment merely as part of the overall exercise, then he was on safe ground, but his decision comes close to elevating subjective views to a decisive element. As we shall see shortly, no one factor is a necessary condition for the existence of a de facto relationship.

Fourthly, it is generally accepted that the person claiming that a de facto relationship existed has the onus of proof. For example in Clitheroe $v$ Parker, ${ }^{29}$ Courtney $\mathrm{J}$ held that a man had failed to discharge the burden, one of the principal pieces of evidence being that the woman spent most of her time with another man.

Finally, on the facts of a particular case, one factor may appear more important than another, and may be influential so long as it addresses the central question of whether the parties were living together as a couple. However, no one factor is necessary or sufficient in determining whether there was a de facto relationship. This is made explicit in subsection (3):

(3) In determining whether 2 persons live together as a couple,-

(a) no finding in respect of any of the matters stated in subsection (2), or in respect of any combination of them, is to be regarded as necessary; and

(b) a Court is entitled to have regard to such matters, and to attach such weight to any matter, as may seem appropriate to the Court in the circumstances of the case.

A Court of Appeal decision in the context of social security benefit fraud, Ruka, had held that financial interdependence was an essential requirement. ${ }^{30}$ This decision related to statutory language that talked about "in the nature of marriage" and placed weight on the statutory framework. The woman was held not to be in a relationship in the nature of marriage and thus not to have committed benefit fraud. The Court accepted that a person may be in the necessary kind of relationship in other contexts, of which property division is surely an example. Section $2 \mathrm{D}(3)$ explicitly reinforces this, as a factor such as financial dependency or intermingling cannot be a necessary requirement for a de facto relationship under the 1976 Act.

\section{In a De Facto Relationship and Not in One - at the Same Time}

The somewhat troubling point remains however that two people may be in a de facto

29 Clitheroe $v$ Parker (23 Nov 2007) HC AK, CIV-2006-404-0046, especially para 67. Along with $L v P$ [Division of property] [2008] NZFLR 401 (HC), this is a judgment where an appeal judge reversed the findings of the Family Court judge in favour of a de facto relationship. In Genc $v$ Genc [2006] NZFLR 1119 and Benseman v Ball [2007] NZFLR 127 the High Court upheld decisions of Family Court judges that there was either no de facto relationship (Genc where the parties began an association in 1994 and married in March 1999; Potter $\mathbf{J}$ agreed with the finding that there was no de facto relationship until just before the marriage) or there was no such relationship at the time when the legislation came into force (Benseman, discussed below in Part IV(f)).

30 Ruka v DSW [1997] 1 NZLR 154 (CA). The Court also pointed to the need for emotional commitment, which was problematic on the facts because the woman suffered from battered woman's syndrome. 
relationship for some legal purposes and not others. Parliament itself reinforced this more recently. An amendment to the Interpretation Act 1999 was added in 2005 and it employs a different definition from that in the 1976 Act. It does not apply to the 1976 Act but will do so to other statutes that do not have their own definition. Section 29A of the Interpretation Act reads as follows:

\section{Meaning of de facto relationship}

(1) In an enactment, de facto relationship means a relationship between 2 people (whether a man and a woman, a man and a man, or a woman and a woman) who-

(a) live together as a couple in a relationship in the nature of marriage or civil union; and

(b) are not married to, or in a civil union with, each other; and

(c) are both aged 16 years or older.

(2) Despite subsection (1), a relationship involving a person aged 16 or 17 years is not a de facto relationship unless that person has obtained consent for the relationship in accordance with section 46A of the Care of Children Act 2004.

(3) In determining whether 2 people live together as a couple in a relationship in the nature of marriage or civil union, the court or person required to determine the question must have regard to-

(a) the context, or the purpose of the law, in which the question is to be determined; and

(b) all the circumstances of the relationship.

Significantly, this definition returns to the phraseology of "in the nature of marriage", adding "or civil union" and treats 16 and 17 year olds differently from the 1976 Act. Subsection (3) follows the Ruka approach of considering the particular piece of legislation under which the issue arises.

Although there has so far been no case law on section 29A - the 1976 Act providing most of the relevant jurisprudence on de facto relationships - there can be no doubt that Parliament had it in mind that the same couple could legally be de facto partners sometimes but not always. For instance in Ruka the woman charged with benefit fraud escaped because of the lack of financial interdependence with the man with whom she was residing. However, on the face of it she could claim half the relationship property. This could work either to her advantage or to her disadvantage. If Ms Ruka had no property of her own, she would get half of the man's relationship property. On the other hand, if he had no property, she may owe him half. She escapes benefit fraud because she was not in a relationship in the nature of marriage, but falls under the 1976 because she was in a de facto relationship.

Does this make a lot of sense? On the one hand, it is correct that the aims of the Social Security Act 1964 and the Property (Relationships) Act 1976 are different. The former is geared to providing State relief to people in financial need, while the latter relates to the division of property built up during the period when two people lived together. For the purposes of the former, a person in a 
relationship who is not supported by the other partner may still be in financial need. Support and need are irrelevant to the division of property (although they may of course be relevant to a claim for maintenance). On the other hand, it is still anomalous to have two distinct tests for what is essentially the same question: were the parties living together in a de facto relationship? Surely it would be better to have one definition for qualifying relationships and deal with the Ruka type situation by rules that directly address the level of financial interdependence necessary to make someone eligible for a social security benefit.

\section{E The Quality of Life Together - Scragg v Scott}

After seven years of the operation of the new legislation, no case on distinctive de facto relationship questions has reached the higher echelons of the New Zealand court system. This may in part be because of the intensively factual nature of most of the inquiries. The leading judgment is that of two High Court judges in Scragg $v$ Scott. ${ }^{31}$ This appeal upheld a Family Court decision that there was a de facto relationship that lasted long enough to provide jurisdiction under the 1976 Act. It raises several valuable points about the concept of de facto relationship.

The parties first got together in 1990, although they had been teenage "sweethearts" much earlier. They had two residences, one in New Zealand, largely provided by the man, where the woman Ms Scott mostly lived, and one on the island of Guam where Mr Scragg ran a business. When they were together in the respective countries, they shared accommodation but the nature of things was that they were apart for considerable periods of time. Both had other sexual partners but a crunch moment came when in July 2002 (that is, after the new legislation came into force) Ms Scott found out that Mr Scragg was living with another woman in Guam. The Family Court judge held that there was a de facto relationship that started in 1996 when Ms Scott acquired property in New Zealand with Mr Scragg's help, and ended in July 2002 on the discovery of the existence of the other woman. The High Court agreed.

The association between these two people was not a classic de facto relationship bearing all the usual indicia of a marriage. They were a couple but were together "off and on". In many ways they kept their separate lives going but nevertheless had an ongoing commitment one to the other. Fidelity did not appear to matter to them and there was no family life in the usual sense, certainly not one with children. Were they "living together as a couple"?

The High Court recognised the variety of situations that may amount in law to a de facto relationship: ${ }^{32}$

The complexity and diversity of human nature and behaviour is such that many types of associations may properly fall into the category of a de facto relationship as envisaged by Parliament. For there to be

31 [2006] NZFLR 1076 per Gendall and Ellen France JJ.

32 Ibid, para 31. 
a relationship there must be an emotional association between two persons. Some associations will clearly be de facto relationships such as where partners are living in the same accommodation, perhaps sharing sexual conduct and proclaiming that they are a de facto couple sharing their lives. At the other end of the scale two persons may simply be lovers living apart and without any special bond or affiliation or emotional association which would place their relationship into the category of a de facto relationship.

In effect, there is a spectrum and various associations will fit somewhere along the line of the spectrum. Mere lovers are at one end, people who share their lives emotionally and physically at the other. Other more problematic situations fall somewhere in between. The High Court also stressed that generalisations were to be avoided: ${ }^{33}$

The test must inevitably be evaluative, with the Judge having to weigh up as best he or she can all of the factors - not only those contained in s 2D, but also any others there may be - and applying a commonsense objective judgment to the particular case.

In looking at the facts of Scragg $v$ Scott, one issue is the lack of a common regular residence. However, this is only one of the factors that goes into the melting pot and is not a necessary condition for a de facto relationship. As Rodney Hansen J said in $G v B:^{34}$

That accords with common sense and experience. There may be compelling reasons why a couple do not share a common residence for substantial periods of time whilst remaining totally committed to a long-term relationship. Ill-health and the need for medical treatment, the demands of employment or studies, responsibility for childcare or other dependants, and financial need may separately or in combination require couples in committed relationships to live apart for long periods of time.

Much may depend therefore on the degree of mutual commitment to the relationship. Scragg $v$ Scott noted that there could be high, moderate or low levels of commitment, but commitment was not capable of easy analysis. This is further complicated where the parties engage in de facto adultery, but such conduct need not be fatal to a finding that there is a de facto relationship: ${ }^{35}$

... there may be many relationships where one or both parties do not limit their sexual behaviour to activity with the other yet they remain married or in a civil union or a de facto relationship. There may be instances where couples in a relationship operate on an understanding that each might have, from time to time, other sexual partners. There may be instances where intermittent sexual behaviour occurs but is kept secret from a partner for many years. Sexual fidelity may be a factor which, depending on the circumstances, may indicate a lack of commitment but it depends on all the circumstances.

33 Ibid, para 37.

34 [2006] NZFLR 1047 (HC), para 33.

35 Above n 31. 
In the end, the Family Court and High Court in Scragg $v$ Scott held that there was sufficient commitment for there to be a de facto relationship. The parties did cohabit whenever they could, even if intermittently - the total number of days actually spent cohabiting was not insignificant. They travelled together and appeared in public together. They did not keep their finances separate. Indeed, Ms Scott was in many respects dependent on Mr Scragg as he provided a rent-free home and assisted with capital for business and investments. Mr Scragg had even prepared an agreement in which he acknowledged the existence of a de facto relationship. All these factors outweighed the other matters that pointed away from a de facto relationship. Had they kept their association more discreet, had they maintained their independence in relation to matters such as finances, or had their emotional commitment been primarily to someone else as in the "dumped mistress" case, then the outcome would likely have been different.

\section{F Ending the Relationship - Scragg v Scott}

Another significant issue in Scragg $v$ Scott was the end date of the relationship. ${ }^{36}$ The date was crucial in deciding whether or not the relationship ended before the legislative changes came into effect. In other cases the point may be important for the purposes of the three-year rule.

As already noted, Mr Scragg and Ms Scott had something of an "off and on" association. In some cases this may lead to a series of de facto relationships, time commencing at "zero" in each instance, rather than one continuing relationship. In one case, for example, it was held that parties who had entered into a formal separation agreement and divided up their resources started a fresh relationship when they got back together again. ${ }^{37}$ This was not the result in Scragg $v$ Scott. Indeed, the implication of this decision is that, absent facts such as those in the previous case, the courts are likely to hold that a relationship continues, even in the face of intermittent partings. Once started, "then an inference may be drawn that the existing relationship continues". ${ }^{38}$ In other words, the onus shifts to the party arguing for an earlier ending date. This may not be easy: "A de facto relationship or the consortium of marriage may be maimed, or in an attenuated form yet be still alive". ${ }^{39}$ This is how the court perceived the facts of Scragg $v$ Scott itself. A lurking doubt remains about the timing. Why did the relationship not end when Mr Scragg began living with the other woman? The answer lies in further evidence showing that outside Guam Mr Scragg and Ms Scott

36 Section 2D(4), Property (Relationships) Act 1976 reads:'For the purposes of this Act, a de facto relationship ends if-

(a) the de facto partners cease to live together as a couple; or

(b) 1 of the de facto partners dies."

37 I v L [2004] NZFLR 714 (Family Court).

38 Above n 31, para 51.

39 Ibid, para 42. 
still travelled together during this time and continued a sexual relationship. Until Ms Scott discovered the truth, there was still an element of mutual commitment to live together as a couple, even in a "maimed" form.

The decision also sits a little awkwardly with Benseman $v$ Ball. ${ }^{40}$ There, a relationship began in 1992 and was held by the Family Court judge to have ended in mid-1999 when the couple no longer shared a common household. That date, of course, was before the 2001 amendment came into force. This finding was upheld on appeal where Priestley J discussed inter alia the importance of a mental element adverse to continued cohabitation. After noting a number of matrimonial cases where the court had to decide for divorce purposes whether the parties were "living apart" and accepting the application of these cases to the same issue in the de facto relationship context, Priestley $\mathrm{J}$ said that: 41

$\ldots$ it would be an error to construe ... para [51] of Scragg $v$ Scott [see above] as authority for the proposition that a de facto relationship remains afoot until such time as one party communicates the end of the relationship to the other. Such an approach would be an over simplification. Cohabitation is an important aspect of the necessary inquiry. But there must also be a focus on whether one party regards the relationship as being at an end. Ultimately ... this will be a matter of inference.

The main piece of evidence of the woman's mental attitude was a will that she made in 2001 shortly before learning that she had terminal cancer and in which she made no provision for Mr Benseman. On the other hand, prior to 1999 the parties had at various times lived in separate towns and cities, so that the change in 1999 was not inconsistent with the pattern of their lives. Furthermore, after $1999 \mathrm{Mr}$ Benseman travelled in order to spend days with the woman, they were in frequent telephone contact and went on outings together. He had been building the woman's house and continued with this until its completion. In the light of all the evidence, could it not just as easily have been inferred that the relationship was, as in Scragg $v$ Scott terms, maimed but alive? As $\mathrm{Mr}$ Benseman described it somewhat ironically, was it not a "never say die, never say good-bye" relationship?

Comparing these two cases illustrates neatly the point that different courts can measure not dissimilar facts quite differently, even when applying the same legal principles.

\section{THE THREE-YEAR RULE}

There is no magic about three years. Arguments can be made that some other period just as adequately serves the purpose of excluding temporary and casual associations from the scope of the

40 [2007] NZFLR 127 (HC).

41 Ibid, para 46. 
statutory regime. ${ }^{42}$ In New Zealand, three years made sense because there is also a three-year rule for marriages (and for civil unions). The difference is that marriages and civil unions of "short duration"43 remain under the Property (Relationships) Act 1976 (but property is likely to be divided according to contributions rather than equally) while de facto relationships of "short duration" fall right outside the Act (unless an exception applies) and any claim must be based on the old rules of common law and equity.

The English Law Commission discusses but does not accept an argument that there should be no minimum duration requirement. ${ }^{44}$ This argument assumes a contributions-based system under which parties to short relationships will often not be able to adduce evidence of contributions that would justify an award in any event. Given that New Zealand's system is based prima facie on equal division, the lack of a minimum period could work unfairly. Arguably, New Zealand could have treated short duration de facto relationships like marriages and civil unions where contributions do become the norm. However, at the time of the passage of the legislation no one appeared to advance this approach.

The exceptions to the three-year rule thus become important. The key provision is section 14A:

De facto relationships of short duration

(1) This section applies if a de facto relationship is a relationship of short duration (as defined in section $2 \mathrm{E})$.

(2) If this section applies, an order cannot be made under this Act for the division of relationship property unless-

(a) the Court is satisfied-

(i) that there is a child of the de facto relationship; or

(ii) that the applicant has made a substantial contribution to the de facto relationship; and

(b) the Court is satisfied that failure to make the order would result in serious injustice.

(3) If this section applies, and the Court is satisfied that the grounds specified in subsection (2) for making an order on an application under this Act are made out, the share of each de facto partner in the

42 For example the English Law Commission considered that a period of between two and five years was possible: Cohabitation: The Financial Consequences of Relationship Breakdown Law Com No 307 (London, 2007) para 3.45.

43 Ie less than three years unless the court extends the time beyond three years (which is hardly ever done): see s 2E, Property (Relationships) Act 1976.

44 Above n 42, paras 3.33-3.41. 
relationship property is to be determined in accordance with the contribution of each de facto partner to the de facto relationship....

Where this section applies, under subsection (3) equal division is replaced by division based on contributions. The section legislates for two exceptions, one based on the presence of a child and the other based on substantial contributions. In both instances, the additional test of "serious injustice" must also be satisfied. A child of a de facto relationship does not have to be a child of the two parties. The child could for example be a child from a previous relationship. The notion of "substantial contribution" is imprecise. Some Family Court judges had talked about departures "from the norm" but this was thought to be of little assistance by High Court judge Asher $\mathrm{J}$ in $L v B$ [Division of property]. ${ }^{45} \mathrm{He}$ took the view that there was no need to refine the meaning of "substantial" beyond its natural meaning of "real importance or value".

"Serious injustice" is also an inherently vague phrase. However, if a person has been disadvantaged because of a child of the relationship or has made a substantial contribution, it is quite likely that the test of "serious injustice" will also have been satisfied. This is the tenor of $L v B$ [Division of property], where Asher J said: ${ }^{46}$

... it would be unusual for there to be no serious injustice if there were a failure to make an order recognising a substantial contribution. However, in considering serious injustice, a comparison of the contributions of each party can be relevant, as can the total value of the relationship property estate. It is only by considering the broad picture in this way that injustice can be evaluated.

And again: ${ }^{47}$

In assessing "serious injustice" it is legitimate to apply the concept of a party getting a just return for

"contributions" ... The concept of a return for contributions and the notion of a constructive trust can be seen as a benchmark of entitlement, against which the position of the applicant if a Court does not interfere can be measured.

Under section 18 of the 1976 Act, contributions are given a wide meaning, certainly not limited to financial and tangible contributions. Anyone who is likely to have a constructive trust claim is also likely to satisfy the serious injustice test as explained by Asher J. Further, there is little point in forcing such a person to resort to common law and equity remedies given that division is based not on equal sharing but on contributions and thus there is little or no unfairness in allowing the court to have jurisdiction under the 1976 Act. In $L v B$ [Division of property] itself the trial judge would have divided the property 60/40 in favour of the man. Asher $\mathrm{J}$ held that the judge had not properly

45 Above $\mathrm{n}$ 20, para 70. This case is discussed above in the context of the existence and commencement of a de facto relationship: Part IV(c).

46 Ibid, para 72.

47 Ibid, para 75. 
compared the parties' respective contributions. In particular he did not give sufficient weight to the man's very substantial contribution to the value of the assets in the light of the shortness of the relationship. On appeal, the property was divided 70/30 in the man's favour.

\section{OPT-OUT RULES}

In New Zealand, there was never any controversy over the concept of de facto partners' contracting out of the 1976 Act. First, agreements between unmarried parties were expressly provided for in 1986 when section 40A was added to the Property Law Act 1952 (now repealed). Secondly, the original Matrimonial Property Act 1976 Act provided for married parties to contract out of the Act, either by way of pre-nuptial agreement or agreement at any time, or by way of settlement of issues after separation. Grafting de facto partners on to these rules was therefore very straightforward.

Under Part 6 of the Act, an agreement must meet certain formal standards, the most important of which is the need for both parties to have independent legal advice. An agreement must also satisfy certain substantive conditions. For example, it may be set aside under the ordinary rules of the law of contract. However, importantly, the court also has power to set an agreement aside on the grounds of "serious injustice". This enables the court to query the fairness of an agreement in terms of both the way in which was obtained and its provisions. For example, too great a departure from the division rules under the statutory scheme may suggest that one of the parties has been seriously disadvantaged. Prior to the changes in 2001, it was thought that the courts had been too liberal in setting agreements aside. Parliament then added "serious" to the notion of unjustness, and in a slightly curious phrase, required the court to have regard to "[t]he fact that the parties wished to achieve certainty as to the status, ownership, and division of property by entering into the agreement". ${ }^{48}$ The latter appears to state the obvious, and does not permit the court to delve into the mental state of the parties as to how certain they wanted things to be. ${ }^{49}$

The result of this is that it is easy enough for de facto partners to opt out of the 1976 Act, so long as they both agree to do so and so long as they can afford the legal fees for two solicitors (neither of which is of course insignificant). However, it would not be usual for the total Act to be "disapplied", to use the English Law Commission's language. A common and largely unimpeachable approach would be for the parties to be keep whatever property they had at the start of their relationship and then share any common property acquired during the relationship.

\section{CONCLUSION}

One of New Zealand leading family law barristers, Simon Jefferson, has said that: ${ }^{50}$

48 Section 21J(4)(e), Property (Relationships) Act 1976.

49 See the leading Court of Appeal decision in Harrison v Harrison [2005] 2 NZLR 349.

50 Simon Jefferson "De facto or 'Friends with Benefits'?" (2007) 12 NZ Family Law Journal 304, 309. 
Beyond stating the obvious (that the Court is required to assess all the evidence and view cumulatively all of the circumstances) the fact-specific nature of the enquiry which must be undertaken in such cases makes it almost impossible to distil any universal principles from the cases which have received judicial consideration.

Indeed, given the inherently volatile condition of human affairs, it is a forlorn task to try and come up with a black and white definition of a de facto relationship. This will be so whether the legislative framework is a unified one as in New Zealand or one where there is separate legislation for de facto relationships. Inevitably there will be difficult cases around the edges, for example where there has been no regular common residence or where there has been infidelity. These fringe cases are the ones that end up in court. In the middle, one suspects that the vast majority of unmarried couples are much the same as married and civil union couples and fall uncontroversially within the framework of any relevant legislation.

\section{POSTSCRIPT}

Since this article was written, the Court of Appeal decided Bourneville v Bourneville. ${ }^{51}$ The case turned on whether a de facto relationship ended in 2000, which was then followed by a new de facto relationship and marriage, or whether there was one continuing de facto relationship followed by marriage. The question was important because the wife challenged the husband's transfer of property to a trust in 1999, before the Act was extended to de facto relationships. The Family Court, upheld by Wild $\mathrm{J}$ in the High Court, decided that the (first) de facto relationship ended in 2000 and therefore there was no jurisdiction. The Court of Appeal declined to grant leave to appeal. In the course of its short judgment, the Court said: ${ }^{52}$

It is not possible to have a blanket rule that treats parties involved with each other on an "on again, off again" basis as being involved in a single continuous relationship. To take an extreme example, assume that two people were in a de facto relationship with one another for several years in the early 1990s then got together as a couple again a decade later, having been involved in other relationships in the intervening period. It is almost inevitable that the later relationship would be regarded as a new relationship rather than as a continuation of the earlier one.

The Court also expressed concern about another problem. This was the "danger" that de facto relationships can be regarded as having ended more readily than marriages. The Court strongly hinted that it would find such a disparity in approaches contrary to the purpose of the Act, namely that married and de facto couples should be placed "on the same footing". ${ }^{53}$

\footnotetext{
51 Bourneville v Bourneville [2009] NZFLR 69.

52 Ibid, para 20.

53 Ibid, para 21.
} 
